\title{
3 次元 CG を用いた景観特性の計量化とそのシステム開発に関する研究 A DEVELOPMENT OF SYSTEM FOR REPRESENTING LANDSCAPE CHARACTERISTICS INDEX USING THREE-DIMENSIONAL COMPUTER GRAPHICS
}

\author{
有馬隆文*, 佐藤誠治**, 萩島 哲***, 坂井 猛**** \\ 趙 世 晨*, 小林祐司***** \\ Takafumi ARIMA, Seiji SATO, Satoshi HAGISHIMA, \\ Takeru SAKAI, Shichen ZHAO and Yuji KOBA YASHI
}

\begin{abstract}
The purpose of this study is to develop the application software for grasping the characteristics of landscape. The used data is digital elevation map (50m Grid) which is published by Geographical Survey Institute in Japan. We simulated geographical environment using this data, sited the eye position and abstracted the characteristics of landscape by calculation of geometry. The characteristics of landscape are expressed by the numerical data and the three-dimensional computer graphics. The numerical data presents the range, distance and direct of view, angle of depression, angle of incidence and others. By comparing these data and computer graphics, we verified the effectiveness of indexes.
\end{abstract}

Keywords: Landscape, Computer Graphics, Digital Map 50m Grid, Visibility and Invisibility 景観，コンピュータグラフィックス，数值地図 $(50 \mathrm{~m})$ ，可視・不可視

1.はじめに

\section{(1) 背景}

地方自治体で策定されている詈観形成基本計画などにみられる 景観整備は、小地区を対象とした景観形成に関する事項が比較的 多い。そこでは、市街地周辺の丘陵地や遠景に見える山々が景観 整備に有効に活用されていないのが実情である。言うまでもなく かつての集落などは、集落を取り巻く自然環境と一体的に整備さ れ、地域独自の「風土」「原風景」が形成されてきた。従って、今 日でもこれらの自然資源を活用した景観整備が必要であり、その ためには、古来より人々に親しまれてきた地域固有の自然景観の 特性を再認識することが重要である。

既に広域的な自然景観の特性を表現する概念や指標は、数多く の提案がなされており、樋口 ${ }^{1)}$ は、眺望の性質を示す指標として、 可視 - 不可視、距離、視線入射角、不可視深度、俯角、仰角、奥 行、日照による陰陽度を指摘し、上原 ${ }^{2)}$ は、眺望の五要素として、 視点、視界、方位、主景、距離を挙げている。しかしながら、指 標として提案されていても、実際の景観から計量することは難し く、地図や写真から計量するにしても極めて多大な労力を必要と することから、定性的に扱われる場合が非常に多かった。一方、 3次元地形モデル注1) から景観特性を定量的に計量する手法も古 くからあるが、指標の具体的な計量法について詳細に言及されて
おらす、また、これまで提案された指標には類似した傾向を示す ものも多いことから、指標の整理と計量手法の明確化が課題とな っている。しかしながら、3 次元地形モデルを用いた計量手法は 兒観特性の定量的表現に優れているため、さらに数多くの指標か 提案され計量手法が確立されれば、景観研究への応用が大いに期 待できる。特に、これまで定性的に論じられてきた「風水におけ る地の利小「地形的条件よって形成された名所・名勝の景観構造 把握」「景観特性と景観評価との関連」は、景観特性を定量的に 表現することによって明らかになるであろう。また、実際の景観 整備事業、計画においても、「地域における景観資源の定量的探 索」「広域的眺望景観を考慮した市街地整備」への利用が期待で きる。以上のことから、景観の特性を 3 次元地形モデルから簡便 かつ一元的に計量し、計量結果を図表により表現するシステムの 開発が求められている。

(2) 目的

本研究の目的は、既往の景観計量指標に加え、新たな指標を提 案し、標高データのみを用いて広域的なエリアにおける景観の特 性を数值データ及び 3 次元コンピュータグラフィックスよりに表 示するシステムを開発することである。

\section{（3）関連する既往の研究}

景観特性を表現する指標は旧来より多数の提案がなされている
* 九州大学大学院人間環境学研究科都市共生デザイン専攻 助教授. 工博

** 大分大学工学部建設工学科 教授 $\cdot$ 工博

*** 九州大学大学院人閏環境学研究科都市共生デザイン尃攻 教授. 工博

**** 九州大学新キャンパス計画推進室 助教授・工博

***** 大分大学工学部建設工学科 助手. 工修
Assoc. Prof., Dept. of Urban Design, Planning and Disaster Management, Graduate School of Human-Environment Studies, Kyushu University, Dr. Eng. Prof., Dept. of Architectural Eng., Faculty of Eng., Oita University, Dr. Eng. Prof., Dept. of Urban Design, Planning and Disaster Management, Graduate School of Human-Environment Studies, Kyushu University, Dr. Eng.

Assoc. Prof., New Campus Planning Office, Kyushu University, Dr. Eng. Research Assoc., Dept. of Architectural Eng., Faculty of Eng., Oita University, M. Eng. 
か、ここでは、広域的なエリアを対象として、 景観の特性をコンピュータの技術により計量 している事例について取り上げてみた。 既往の研究において提案された代表的な指 標をまとめたものが表 1 である。本表では、 これらの指標を、計量の対象が視点場である のか、あるいは、視对象であるのかによって 整理している。

表中の「視対象特性指標」とは、視対象の 景観特性を表現する指標である。計量の対象 は、山、河川、海岸線といった個別の景観要 素であるか、もしくは、視対象の領域を一様 にサンプリングした任意の地点である。既往 の研究を見ると、樋口 ${ }^{1)}$ は、山への距離・仰 角、水面への俯角等を計量し、個別の景観要 素の特性を明らかにしている。また、山田 ${ }^{3)}$ や小柳 ${ }^{4)}$ は、視対象エリアをメッシュに区切 り、各メッシュにおける可視・不可視や仰角・ 侮角、視線入射角の特性を明らかにしてい る。これらの指標は景観要素あるいは視対象 の地点毎にデータが抽出されるため、視対象 エリア全体の特性を把握するには、地図上に データをプロットしたり、メッシュデータの 濃淡マップによって表現する必要がある。

次に「視点場特性指標」とは、視点場を計 冝の対象とし、その視覚的な特性を数値デー タとして表現したものである。指標をみると 視覚的な「壆」に関するものが多く、両角ら 7) 飯塚 ${ }^{8)}$ は、立体視野領域、山の可視量と いう指標により、視野空間の大きさ、対象物 の視覚的な大きさを定量的に論じている。ま た、石田ら ${ }^{5)}$ は視点を取り巻く地形の特徵を 定量的に表現する指標を提案している。

本研究では、既に提案された代表的な指標 に、独自に考案した指標を加え、景観特性を 計量するシステムを開発した。

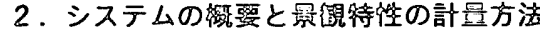

景観の特性を把握する手法としては、実 空間から測量によって計量する方法、写真 や地図といった 2 次元的媒体を用いる方法、コンピュー夕の仮想 空間に地形をシミュレートし、この中から計量する方法がある。

本研究では、第 3 のンピュー夕を用いた計冒手法を用いシステ ムを構築した。本手法のメリットは、景観の特性を立体幾何学の応 用により解析的に計量でき、また、現地測量や地図・写真では、計 量不可能な暍観の特徵を抽出できる点である。以下に本論で提案し たシステムの概要を図 1 のフローに従い述べる。

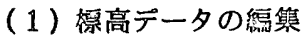

分析に用いるデータは標高データのみであり、本システムでは、 まず最初にデータの編集をおこなう。使用した標高データは国土

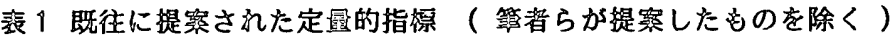

\begin{tabular}{|c|c|c|}
\hline & 視对缘特性指標 & 視点場特性指梛 \\
\hline 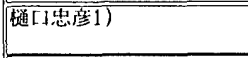 & 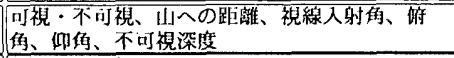 & \\
\hline (116日学3) & 可視・不诃視 & \\
\hline 小柳武和4） & 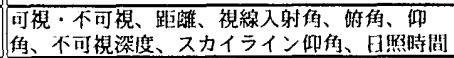 & \\
\hline 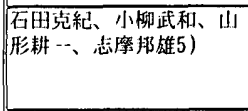 & & 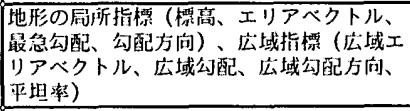 \\
\hline $\begin{array}{l}\text { Burrough, P.A. and De } \\
\text { Veer, A.A.6) }\end{array}$ & landscape maps & \\
\hline 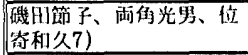 & 律物による不问視領域影筑傮 & 舅瀵球を用いた立体視野領域 \\
\hline 钣㙇英龉:8) & & 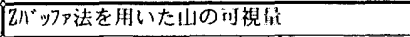 \\
\hline
\end{tabular}

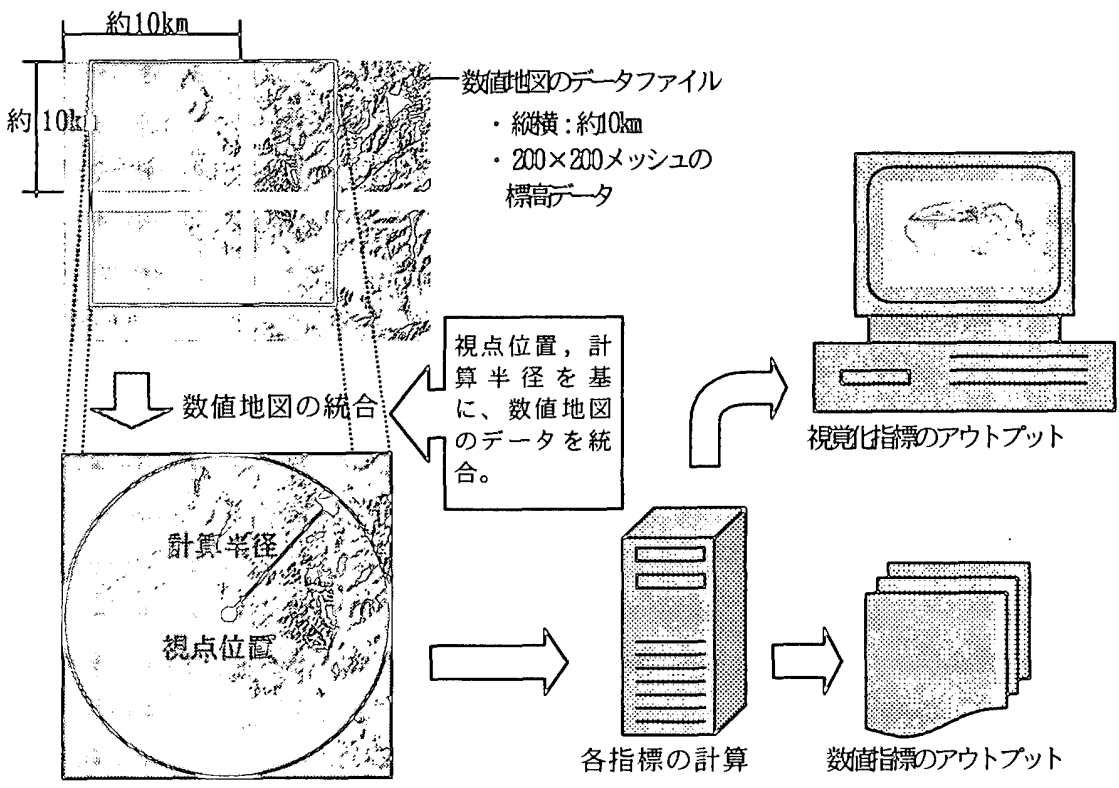

图 1 システム全体のフロー

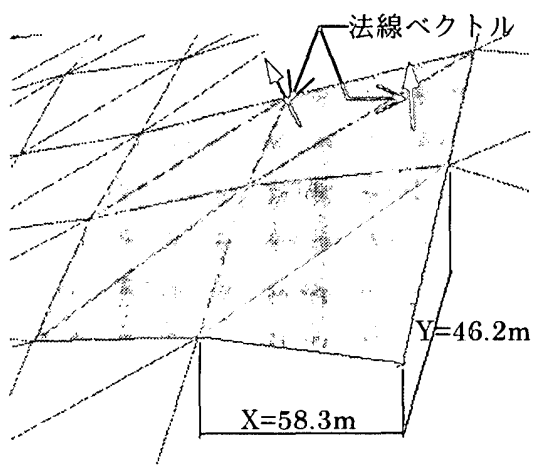

娄 2 地形ハッシュ

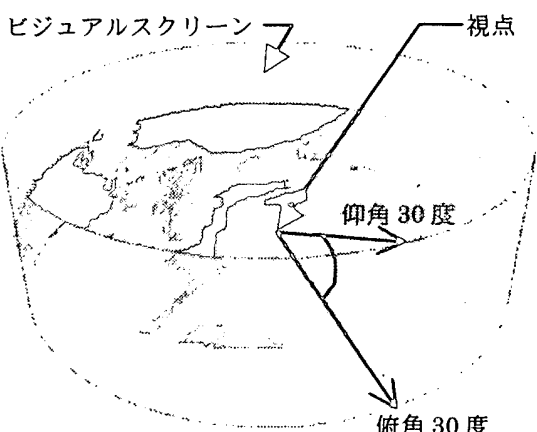

图3ビジュアルスクリーン蜂念図
地理院から市販されている「数值地図 50匹（標高）」洁2)である。 本データは、日本国土の標高を $50 \mathrm{~m}$ メッシュ間隔でサンプリン グしており、広域的な地形を精度高くシミュレートできる。また、 標準化されたデータであるため、汎用的なシステム開発に適して いる。

データは、図の左上に示すように約 $10 \mathrm{~km} \times$ 約 $10 \mathrm{~km}$ の範囲が 1 つのファイルとなっている。本システムでは、視点場周囲 360 度、

一定半径内の領域を計量の対象としていることから、図に示すよ うに、視点位置の緯度・経度および計算半径の值に応じて、計算 範囲をカバーする方形のエリアの標高データを統合した。 


\section{（2）景観特性の計量}

次に統合した標高デー夕を用いて景観特性の計量をおこなう。 図 2 は、標高データをC Gによって抎大表現した図である。1 メッシュの大きさは、X方向 (東西) $58.3 \mathrm{~m} 、 \mathrm{Y}$ 方向 (南北) 46.2 $\mathrm{m}$ であり、九州北部の緯度、経度をもとにサイズを決定してい る注3)。本研究では、この 1 メッシュを 2 つの 3 角形 ポリコンに分割して地表面を表現し、本モデルから各 種の指標を計量した。また、一部の指標は、ビジュア ルスクリーンと呼ばれる媒体を利用し計量を行った。 ビジュアルスクリーンとは、視点より、ある一定距離 離れた位置に円筒状のスクリーンを用意し、地形を構 成する 3 角形ポリゴンをスクリーンに投影したもので ある(図3 参照)。すなわち、ここで描かれる写像は、 人間が視覚的に認知する像に近いと言える注4)。スク リーンの下限は、人間のディスプレイに最適な領域注5) が俯角 0 度〜 30 度であることから、俯角 30 度を下 限值とした。スクリーンの上限は、水平線を人間が見 た場合、色彩を識別できる最大仰角が 30 度であるこ とから、本值を上限值としている。図4 は、円筒状の ビジュアルスクリーンを切り開いた展開図である。本 図から、スカイラインの特性、視覚像の特性を計量し た。

計量に用いた指標をまとめたものが表 2である。指 標は「数値指標」と「視覚指標」に分けられる。

「数值指標」とは景観の特性を 1 つの数值データと して表現したものであり、例えば「可視領域割合(N3)」 は、分析対象となるエリア面積に対する可視エリア面 積の割合であり可視領域の大きさを数値として表わし たものである。一方、「視覚指標」とは、景観の特性を 3 次元 CG により視覚化することによって、人間が目視によりその特徴を読 み取ることができる指標である。例えば、「可視領域(V1)」は、地 形を可視と不可視によって色分けし 3 次元 CGによって表現したも のである。

数值指標は 32 指標、視党指標は 14 指標であり、多角的に景観 の特性を把握できるように指標を選定している。なお、表中の* がついた指標は、本論文にて新たに提案した指標である。

\section{(3) 算定結果のアウトブット}

本システムでは、最終的に上記に挙げた 2 種の指標の算定結果 をアウトプットする。数值指標は数值データの表として表現され、 視覚指標は、3 次元コンピュータグラフィックスあるいはビジュ アルスクリーンの展開図によってコンピュータのディスプレイ上 に表示される。

以上のプロセスにより、景観特性の計量をおこなった。

\section{3. 数値指標}

本システムで用いた数值指標は、表 2 に示すとおり「視点場」「視 対象」「方向」「視界、開放性」等の項目に分けられる。景観はく 見る・見られる>という相対的関係にあることから、それぞれの 指標は、他の項目にも関係づけられるものもあるが、各指標の意

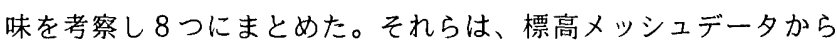

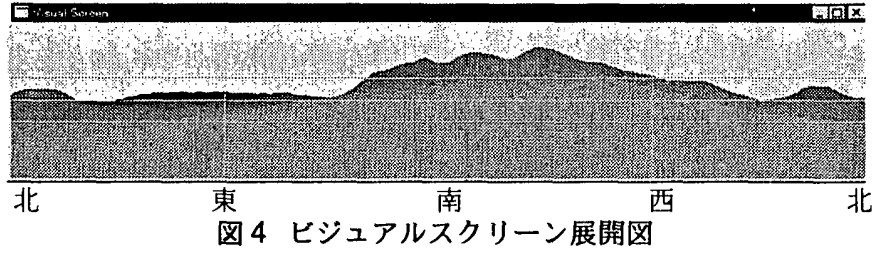

表 2 計量に用いた指標

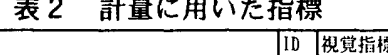

\begin{tabular}{|c|c|c|c|c|}
\hline & ID & 数犆指摽 & ID & 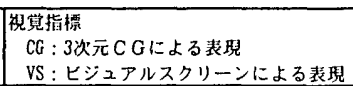 \\
\hline \multirow[t]{2}{*}{ 祝点埸 } & N1 & 选点埸の摽离 & & \\
\hline & N2 & 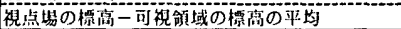 & & \\
\hline \multirow{18}{*}{ 梘対象 } & N3 & 可能領域搉合 & $v_{1}$ & 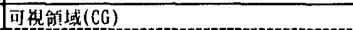 \\
\hline & N4 & 可视领域の標离の平均 & & \\
\hline & N5 & 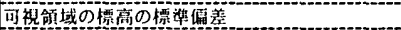 & & \\
\hline & & 可視領域に持ける地形權成割合 & iv2 & 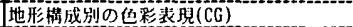 \\
\hline & N6 & 海の權成要繁割合 & - & \\
\hline & N? & 平地の稓成要䋈割合 & & \\
\hline & 108 & 科面の满成要案割合 & & \\
\hline & $\mathrm{Ng}$ & 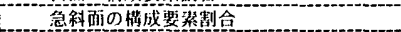 & & \\
\hline & N10 & H模成要學㓶合 & & \\
\hline & & 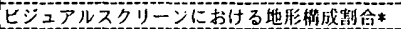 & vis & 地形䖝成別 \\
\hline & Niii & 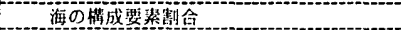 & 1 & \\
\hline & N12 & 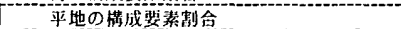 & $\cdots$ & \\
\hline & M13 & 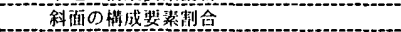 & & \\
\hline & N144 & 急斜面の椑成要䋈制合 & . & \\
\hline & N15 & 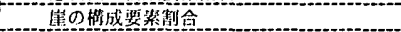 & & \\
\hline & Nii6 & 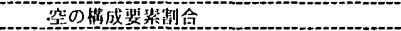 & & \\
\hline & N17 & 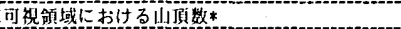 & Ji4 & 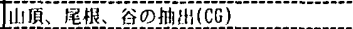 \\
\hline & M18 & スカイラインを䧼成する山激数 & iv & スカイラインを梇成するU頂の装示(VS) \\
\hline 方间 & N19 & 可視畣域のT心の方向 & $v_{6}$ & 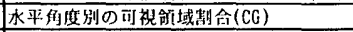 \\
\hline \multirow{5}{*}{ 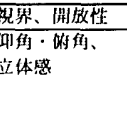 } & $\mathrm{N2O}$ & 水平見通し领域制合* & 177 & 水暃兒通し颌域 (CG)* \\
\hline & N21 & 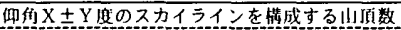 & 18 & 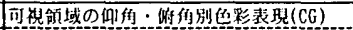 \\
\hline & 122 & 付们 $\mathrm{X} \pm \mathrm{Y}$ 度の可視㓣域㓶合 & 199 & 仰值別の色彩裴現(VS) \\
\hline & 223 & 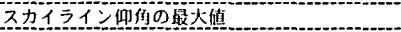 & & \\
\hline & N24 & スカイラインの仰角・树何の㾏 & & \\
\hline \multirow[t]{5}{*}{ 距踓・为行き } & & 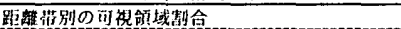 & V10 & 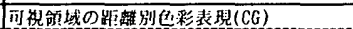 \\
\hline & 225 & 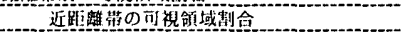 & vi1 & 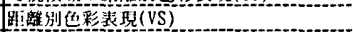 \\
\hline & N26-6 & 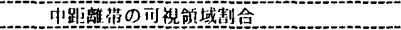 & & \\
\hline & N27 & 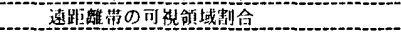 & & \\
\hline & N28 & 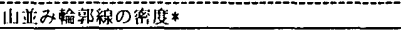 & vi2 & 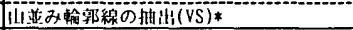 \\
\hline \multirow{3}{*}{ 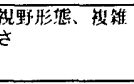 } & 2129 & 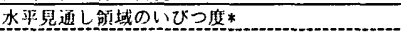 & & \\
\hline & $N 30^{-}$ & 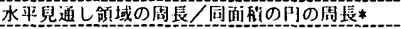 & & \\
\hline & N3is & スカイラインの裸敘さ。 & & \\
\hline \multirow[t]{2}{*}{ 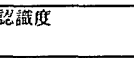 } & N32 & 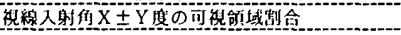 & $\sqrt{\mathrm{V} 13}$ & 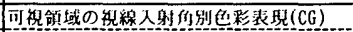 \\
\hline & & & vis & 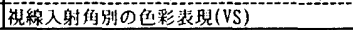 \\
\hline
\end{tabular}

計量する指標と、ビジュアルスクリーンから計量する指標の 2 種 で構成される。

(1) 標高メッシュデータからの計量

(1)可視領域割合 ( I D 番号 : N 3)

可視領域割合とは、計算対象エリアの面積に対する可視エリア の面積の割合を指標化したものであり、視点場周囲の地表面がど の程度見えるかを表現するものである。本指標は既往の論文でも 提案されているが、他の指標のベースとなるものであることから、 敢えて記述した。

$$
\text { 可視領域割合 }=100 \times \frac{\text { 可視ポリゴン面積 }}{\text { 計算エリアの全ポリゴン面皘 }}
$$

本指標を算出するには、視対象の 3 角形ポリゴンに対し可視・ 不可視の判定をおこなう必要がある。これまでの既往の文献では、

「視点と参照点となる地点を結ぶ直線が他の地形ポリゴンに阻害 されるか否かによって可視、不可視を判定する」と記述されてい る。しかし、精密に可視領域を判定するならば、視対象のサンプ ル点は膨大な数となり、他の地形ポリゴンに阻害されるか否かの

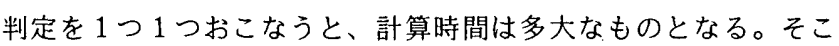
で本システムでは、3つのステップにより高速化を試みた。第 1 のステップは、「計算範囲の限定」である。視点場周囲の 360 度の 視野範囲について解析するわけであるが、計算領域の距離を設定 
し、その距離以上のメッシュについては可視、不可視の判定から 事前に除外した。第 2 のステップは、「法線ベクトルの向きの判定 (図2参照)」である。本ベクトルが、視点場の方向を向いてなけ れは、見えないポリゴンであり、これらのボリゴンについても可 視・不可視の判定から事前に除外している。以上の前処理の後、 可視・不可視の判定をおこない、計算の効率化を図っている。

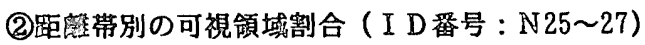

疑口は「景観の構造」 ${ }^{11}$ のなかで、樹木が織り成すテクスチャ 一は距離によって大きく異なることを指摘しており、近景、中景 観、遠景の見える量は景観を特徵づける重要な要素と言える。本 システムでは、地理的スケールの景観を題材としているため、樋 口氏が挙げた距離区分をもとに、近景 $300 \mathrm{~m}$ 以内、中景 $300 \mathrm{~m} \sim 5 \mathrm{~km}$ 、 遠系 $5 \mathrm{k}$ 以上と設定し、各距離帯別のポリゴン数と距離帯別の可 視ポリゴン数を算定して、その割合を求めた。

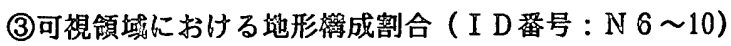

可視領域を明らかにするだけでなく、可視領域内にどのような 地形状況がみられるのかを明らかにすることは重要である。本指 標は、地形の勾配を各 3 角形ポリゴンの法線ベクトルの角度より 求め、勾配が 3 度以下ならば平地、 3 度〜 15 度ならば斜面、15 度

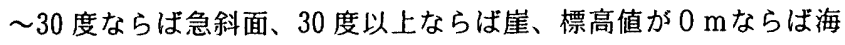
と判定し、その構成割合を算出したものである。図 5 は地形構成 の判定結果を 3 次元 C G よよって表現したものである。

(4)可視領域における山頂效（I D 番号:N17)

視界を取り巻く山頂の数を指標化し たものである。山頂の判定は、微地形 の変化を取り除くため、スムージング 処理を施したあと、任意のメッシュメ、 y の標高値とそれを取り巻く 8 近傍の 標高值と比較し、近傍の全ての標高値 よりも大きければ山頂と判定した。し かし、この方法のみでは、緩やかに地 形を形成する山頂は抽出されない場合 があるため、さらにその周囲の 16 近 傍のうち、任意のメッシュ $\mathrm{x} 、 \mathrm{y}$ に対

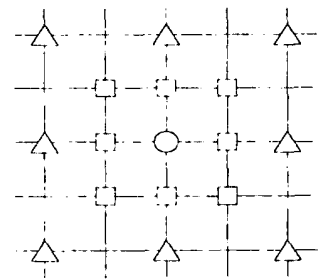

$\bigcirc$ 中心 $\mathrm{x} 、 \mathrm{y}$ の標高值 [.] 周囲 8 近傍の標高值 16 近傍のうち分析に 用いた 8 つ標高值

図 6 山頂抽出に用いた座㫽 し水平、垂直、45 度方向の 8 つの標高值と中央のメッシュの標高 值との比較をおこない、8つの標高值が中央の任意メッシュの標 高值よりも低ければ山頂と判定した（図 7 参照)。

(5)水平見通し領域割合 (I D 番号 : N20)

水平な見通しの大きさを計量するため、図 8 のように、視点と 同一の高さに、視点を中心、算定距離を半径とする仮想の円を設 定し、この円周上へ 1 度刻みに視点から線分を伸ばす。このとき、 線分は、地形ポリゴンあるいは円周に交わる。これらの全ての交 点を順次結べば、360 角形のポリゴンが形成される。すなわち、 このポリゴンの大きさは、見通しの水平的広がりを表現すること から、このポリゴンを水平見通し領域と定め、この面積を円の面 稘で除し、その割合を求めた。

(6)水平見道し領域のいびつ度 (I D 畄号 : N29)

本指標は、水平見通し領域の形状が単純な形態か、あるいは、 眺望が山々に分断された複雑な形態なのかを示す指標である。図 9 の式からも判るように、本指標は僢り合う角同士の変化の大き

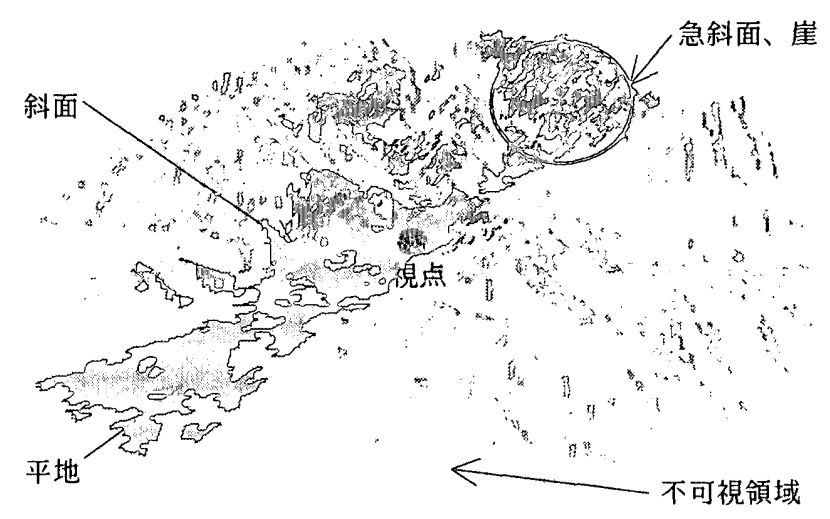

图 5 地形簿成割合の分布

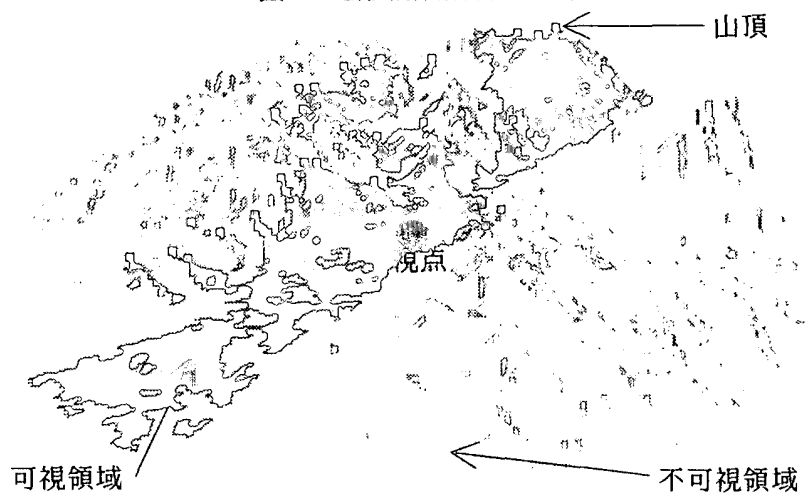

图 7 可視領域における山頂の抽出

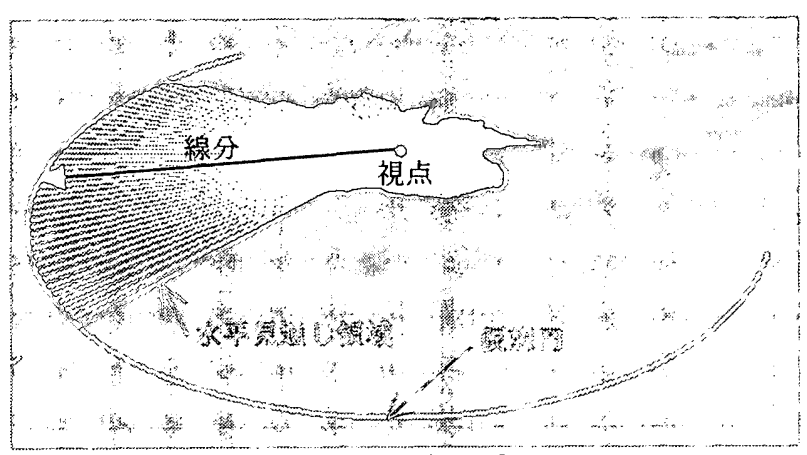

図 8 水平可䘽領域

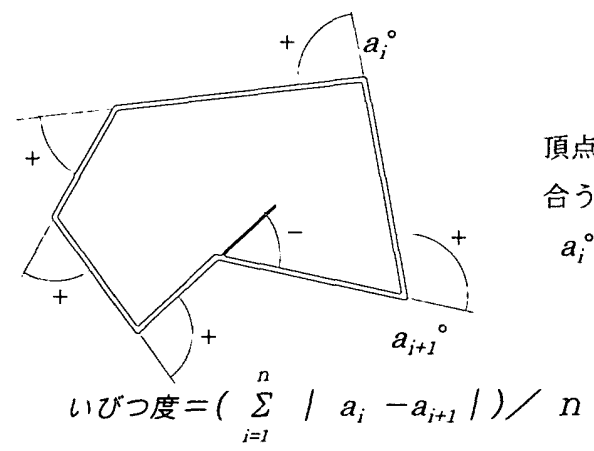

頂点数 $=\mathrm{n}$, 榉り

合う角をそれぞれ

$a_{i}^{\circ} \quad a_{i+1}^{\circ}$ とする

图 9 いびつ度計算法

さを指標化したものであり、正 $\mathrm{n}$ 角形では0、凹角を有するいび つな形態ほど值が高いという特性をもつ。なお本指標は、「地形メ ッシュサイス」と「水平見通し領域を構成する頂点数」に依存す る不安定な指標である。そこで、筆者らは $500 \mathrm{~m}$ 程度の尾根や谷の 起伏状況を反映した「いびつ度」の值を求めるために、「いびつ度」 
の算出結果と 3 次元 CG の「水平見通し領域」の形状を目視によっ て比較しながら、「水平見通し領域を構成する頂点数」を決定し、

「地形メッシュサイス」の妥当性を確認した。

水平見通し領域の周長／同面樌の円の周長 ( I D 番号 : N30)

本指標も水平視野領域の形態特性を表現する指標である。上記 のいびつ度は角度の変化の大きさを表わす指標であるのに対し、 本指標は、水平視野領域が円形に近いかどうかを示すものである。

（2）ビジュルスクリーンからの計量

(1)ビジュアルスクリリーンにおける地形構成割合（ＩＤ番号：N11〜16）

地形構成割合は、仮想の 3 次元空間における地形モデルから計 量できるか、人間の視覚的に捉える地形構成割合とは異なる。な ぜならば、人間が視覚的に捉える量は、視对象のメッシュの距離 と傾斜とその方向に影響されるからである。本指標はメッシュの 距離、傾斜、方向から解析的に算出できるが、計算の効率化のた めビジュアルスクリーンから計量している。具体的には図 10 に示 すようにビジュアルスクリーンの展開図を描く際に、3 角形ポリ ゴンを地形構成別に色分けして表示し、画かれた画像におけるピ クセルの色彩情報を集計することで、視覚的な量を把握した。な お、本指標は距離帯区分ことに計量可能である。

(2スカイラインの複雑さ（ＩＤ番号：N31）

視点を取り巻くスカイラインが険しいか、あるいは、なだらか なものなのかを表現するため、ビジュアルスクリーンの展開図か らスカイラインの波形を抽出し、その標準偏差を指標とした。ス カイラインの波形は、ビジュアルスクリーンの空の領域に接する ピクセルを画像の色彩情報から抽出し、その 2 次元座標をデータ 化することで抽出できる。図11の太線が抽出されたスカイライン である。

(3)スカイラインを構成する山頂数（I D 番号：N18）

視点から可視である山は無数にあるが、その中でもスカイライ ンを構成する山々は極めて視覚的に印象深い要素である。そこで、

これらの山頂数を指標とした。山頂の抽出は、スカイライン波形 のピーク值を抽出すればよい。我々は微地形の変化を取り除くた め波形のスムージング処理を施した後、ピークを抽出し、その数 をカウントした。図11の四角いマークが抽出された山頂である。 (4)山並み㖮部線の密度 (I D 番号 : N28)

日本のように起伏に富んだ地形では、山々の重なり合いが奥行 き感を生み出している。そこで、 我々は、山並み輪郭線をビジュ アルスクリーンの画像から抽出 し、その線の密度を指標化した。 本分析で用いるビジュアルスク リーンの展開図は、3角形ポリ ゴンを視点からの距離に応じて 色分けしたものである。本画像 から色彩情報を読み取り、極端 に色彩が変化する境界を輪郭線 とみなし抽出した。色彩変化は 画像の垂直方向のピクセル同士 を比較することから、画像の縦 方向を 2 倍に拡大し精度高く計

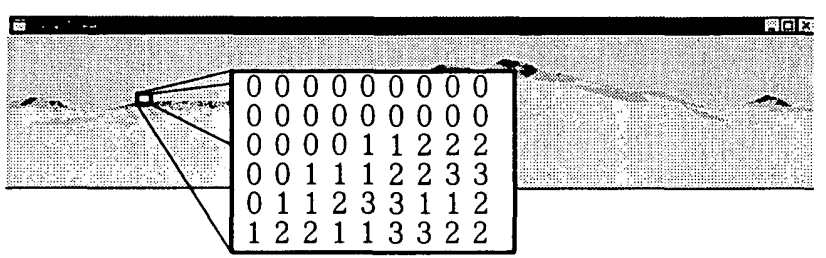

図 10 ピジァルスクリーンのピクセルテータ

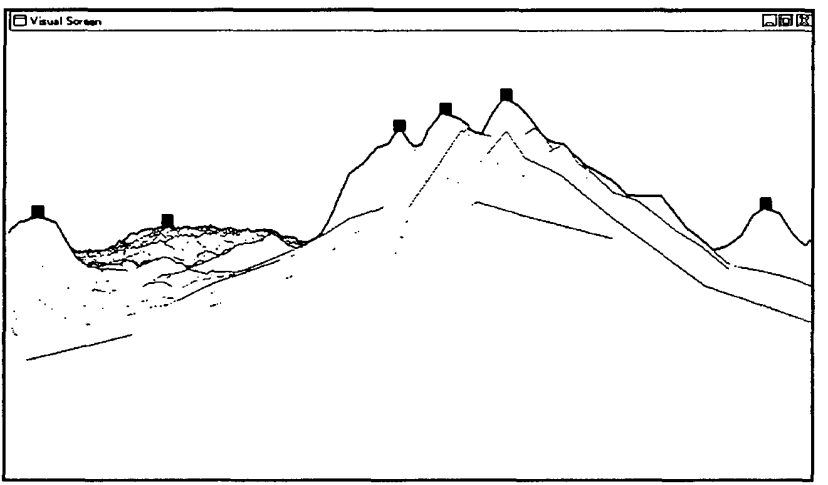

図 11 スカイライン、山頂、山並み䑳郭線の抽出

測している。図 11 に示すラインが山並みの輪郭線である。本輪郭 線を構成するピクセル数を画像全体のピクセル数で除し、その密 度を求めた。

\section{4. 視覚指栐}

視覚指標についてまとめたものが表 2 の右側である。これらの 指標は、3 次元コンピュータグラフィックスあるいはビジュアル スクリーンの手法によって、実空間では捉えることが難しい現象 を視覚的に表示し、景観の特性を把握できるようにしたものであ る。代表的な視覚指標を次に挙げる。

(1)可視領域 ( I D 番号 : V 1)

3 次元マップ上に、ある任意の座標から見える領域を色分けし 視覚的に表示するものである。

(2)地形構成別の色影表現 (I D 番号 : V 2)

可視領域を地形構成別（海、平地、斜面、急斜面、崖）に色分 けし視覚的に表示するものである(図 5 参照)。

(3)可視領域の距離別色彩表現 (I D 番号 : V10)

可視領域を近景、中景、遠景の距離帯に応じて色分けし視覚的

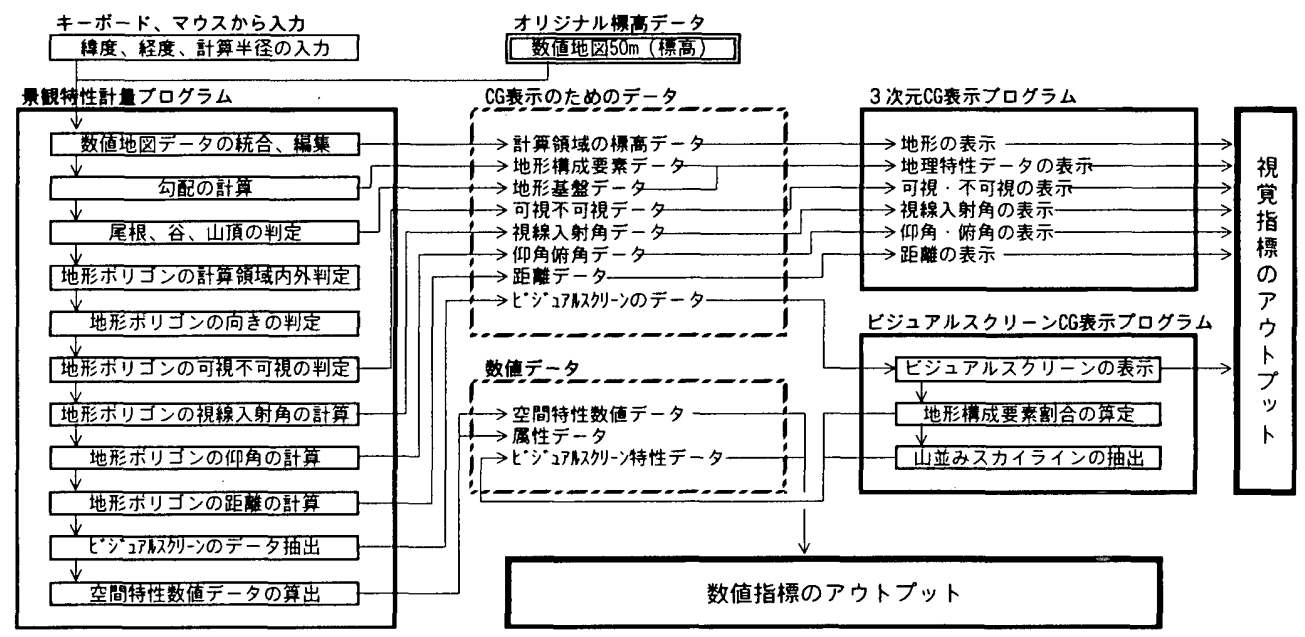

図 12 システムの構成 
に表示するものである（図 14 参照）。

(4)可視領域の仰角・俯角別色彩表現 (I D番号: V 8)

可視領域を仰角、俯角の角度に応じて色分けし視覚的に表示す るものである（図 16 参照）。

(5)可視領域の視線入射角別色彩表現（I D番号：V13）

可視領域を視線入射角の角度に応じて色分けし視覚的に表示す るものである(図 15 参照)。

\section{5. システムの權䇬}

以上の数值指標、視觉指標を計量し表示するシステムのプログ ラムとデータの流れを示したものが図 12 である。

システムは、景観の特性を抽出する「景観特性計量プログラム」、 解析結果を 3 次元コンピュータグラフィックスによって表示する 「了次元 CG 表示プログラム」、ビジュアルスクリーンの展開図を 表示する「ビジュアルスクリーンCG 表示プログラム」から構成さ れる主6)。以下にシステム全体のフローについて説明する。

(1) 入力

景観特性計量プログラムの計算は、視点場の緯度、経度の座標 と計算半径を入力するのみで行われる。これらの值は、図 13 に示 すようなインターフェース画面に地図を表示しマウスよって入力 する。また、視点位置を詳細に入力したい場合はキーボード操作 によっておこなう。なお、このときに、画面右手のオプションメ ニューによって計量する指標を選択することもできる。これらが 入力されると、視点の位置、標高值が確定され、視点を中心とす る「数值地図 $50 \mathrm{~m} 」 の$ 標高データが自動的に読み込まれる。

(2) 計量とアウトプット

景観特性計量プログラムの計算手順は図 12 に示す通りであり、 計算対象地域の勾配計算、尾根、谷、山頂の抽出を行った後、可 視・不可視の前処理、可視・不可視判定を行い、可視ポリゴンの みについて視線入射角、俯角、距離、ビジュアルスクリーン等の 計算を行う。生成される中間データは「CG 表示のためのデータ」 と「数值データ」である。「CG 表示のためのデータ」は計算対象 エリアの全ての 3 角形ポリゴンにおける情報をデータ化したもの であり視覚指標のグラフィックスの表示に利用される。「数值デー タ」は数值指標の值をアウトプットしたものであり、これらのデ 一タは集計や因子分析のオリジナルデータとなる。

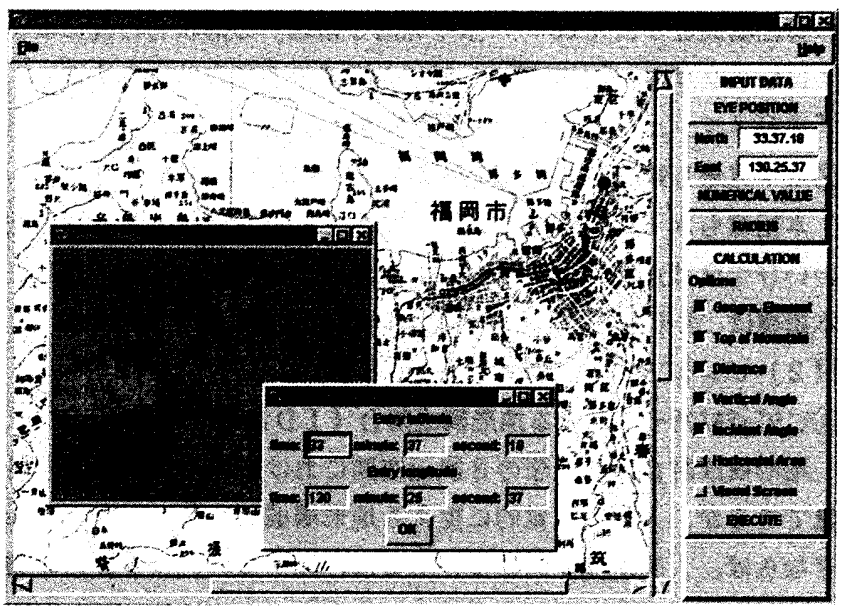

図 13 景観特性計量プログラムの画面

（3）使用機器

ハードウエアは、汎用性を考虑しWindows95 が稼動する DOS/V マシンを使用しているが、UNIX を OS とするワークステーショ ンにも移植可能である。なお、計算領域を大きくすると算定時間 が多大なものとなるため、CPU は 400MHz 以上を使用している。

\section{6. 算定及び表示の事例}

\section{（1）数值指標の算定事例}

福岡県名所図会に画かれた $5 つ の$ 代表的な地点を視点場として、 数值指標を計量した。これらの地点は、筆者らが既往におこなっ た名所図会に関する研究 12）13)において抽出された景観類型の代 表的視点場である。計算半径は $10 \mathrm{k} \mathrm{m}$ と設定し、表 3 に示した指

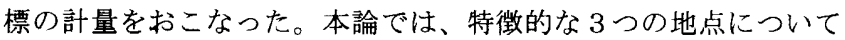
考察し、各指標と図 14〜16 を見比べながら指標の有効性について 検証してみた。

(1)鳥飼神社（図 14 参照）

視点は低地に位置し、視対象もそれほど標高值は高くない (ID1, 2)。視対象についてみると、空間的には海の割合が大きい （ID6）が、海は中景以遠に位置することから、視覚的には平地の割 合が大きい(ID12)。視界は北側の海へ開け (ID19)、可視領域割合 (ID3)、水平見通し領域割合（ID20）も大きいことから眺望にも優れ ているといえる。高仰角の山はなく(ID22, 23)、緩やかな山並みを 呈している(ID35)。

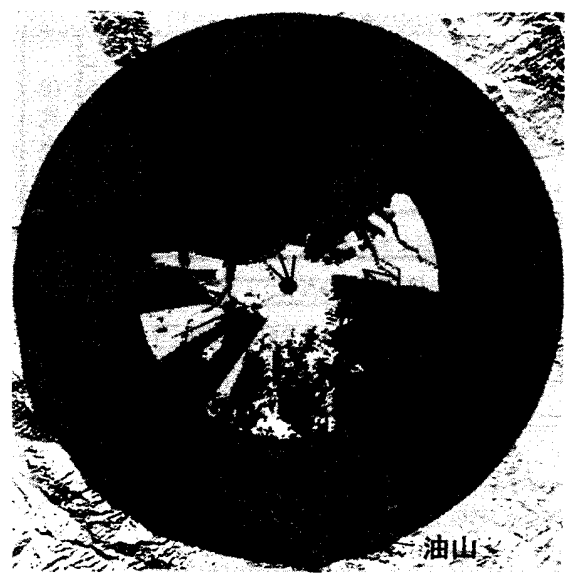

図 14 距離帯別の可視領域

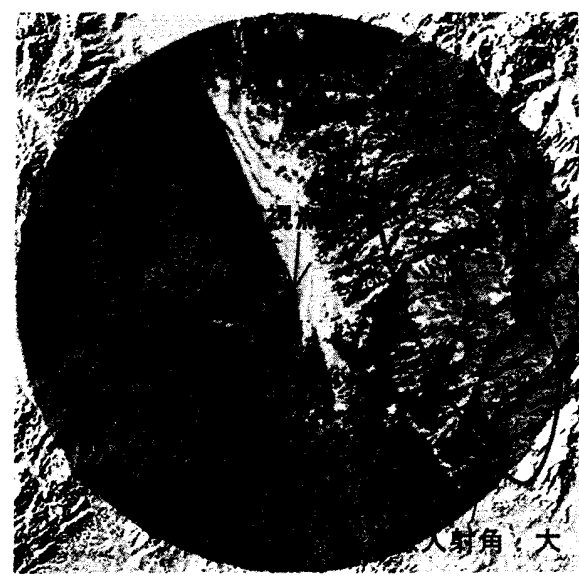

図 15 視線入射角別の可視領域

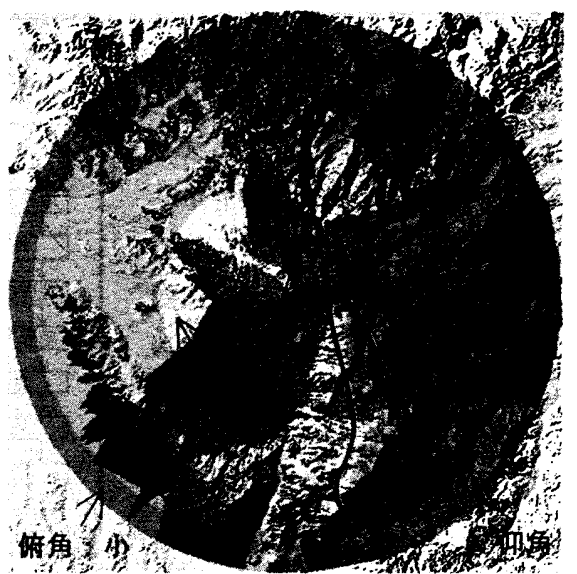

図 16 仰角・俯角別の可視領域 


\section{(2)多賀神社（図15 参照）}

視点の周囲には高い山々が存在し(ID2)、可視領域の標高の標华 偏差も大きいことから起伏に富んだ地形である(ID5)。視対象つい てみると、平地の割合が最も大きいが、他の類型と比べると斜面 の割合が大きいことが伺える(ID7,8)。しかしながら、高仰角の山 はなく(ID22,23)、スカイラインもそれほど複雑ではない(ID35)。 また、視線入射角の大きい面が多く、東側の山々が大きく影響し ている(ID38, 39)。

\section{(3)大祖神社（図 16 参照）}

視点は山頂に位置することから、周囲の標高はかなり低く、周 囲を見下ろす景観である(ID1，2)。したがって、水平的な見通し、 空の見える割合も大きく開放的な特徵を有し(ID20,16)、山々の重 なりも多く見られる(ID32)。視対象についてみると、空間的には 平地の割合が大きい(ID7)が、視覚的には斜面の割合が大きい (ID13)。また、視線入射角の大きい面が多く、立体感のある地形 といえる(ID38, 39)。

\section{（2）視覚指標の算定事例}

ここでは、距離帯別、視線入射角別、仰角・俯角別に可視領域 を色分けした事例を紹介する。

\section{(1)距離帯別の可視領域（図14参照）}

鳥飼神社を視点場とする可視領域を距離帯別に示したものが図 14 である。図をみると、平野部の広域的エリアが視対象となって おり、福岡市のランドマークである油山が遠景に位置することが伺える。 (2)視線入射角別の可視領域 (図 15 参照)

多賀神社の可視領域を視線入射角別に示したものが図 15 である。 南北に走る平野部の東側に金剛山、雲取山、福智山の山々が屏風 状の地形を形成し、視線入射角が大きいエリアを形成している。 (3)仰角・俯角別の可視領域（図 16 参照）

大祖神社を視点場とする仰角・俯角別の可視領域を示したもの が図 16 である。図をみると、視点場は山頂に位置し、西側に大き な可視領域が広がっている。視点場の近距離には俯角が大きいエ リアがあり、また、南側には谷越しに仰角のエリアが分布する。 以上のことから、立体感のある詈観を構成していると言える。

\section{（3）数值指標、視覚指標の評価}

数值指標を 3 次元 CG と比較しながら各事例を個別に考察した結 果、各指標は景観の特性を明確に表現している。しかしながら、CG が提示されなければ、数值デー夕のみから景観の具体的なイメ一 ジを想像することは難しいというデメリットもある。一方、視覚 指標は、人間が景観特性を感覚的に把握する上で優れているが、 視覚指標のみで特徵を論じることは、定性的な議論に終始しがち である。以上のことから、両指標は互いに補完的な関係があり、 両指標を併用し考察することが最も適切であると言える。

\section{7. まとめ}

上記のように標高データのみを用いて景観の特性を簡便に計量 するシステムを開発したわけであるが、本システムの有効性と発 展性及び問題点についてまとめると、以下のことが挙げられる。

（1）算定事例において景観の特性を考察した結果、各指標は景 観の特徵を明確に示していたことから、システムの有効性は高い。

（2）数值指標と視覚指標は互いに補完的な関係があり、両指標
表 3 数值指標の算定

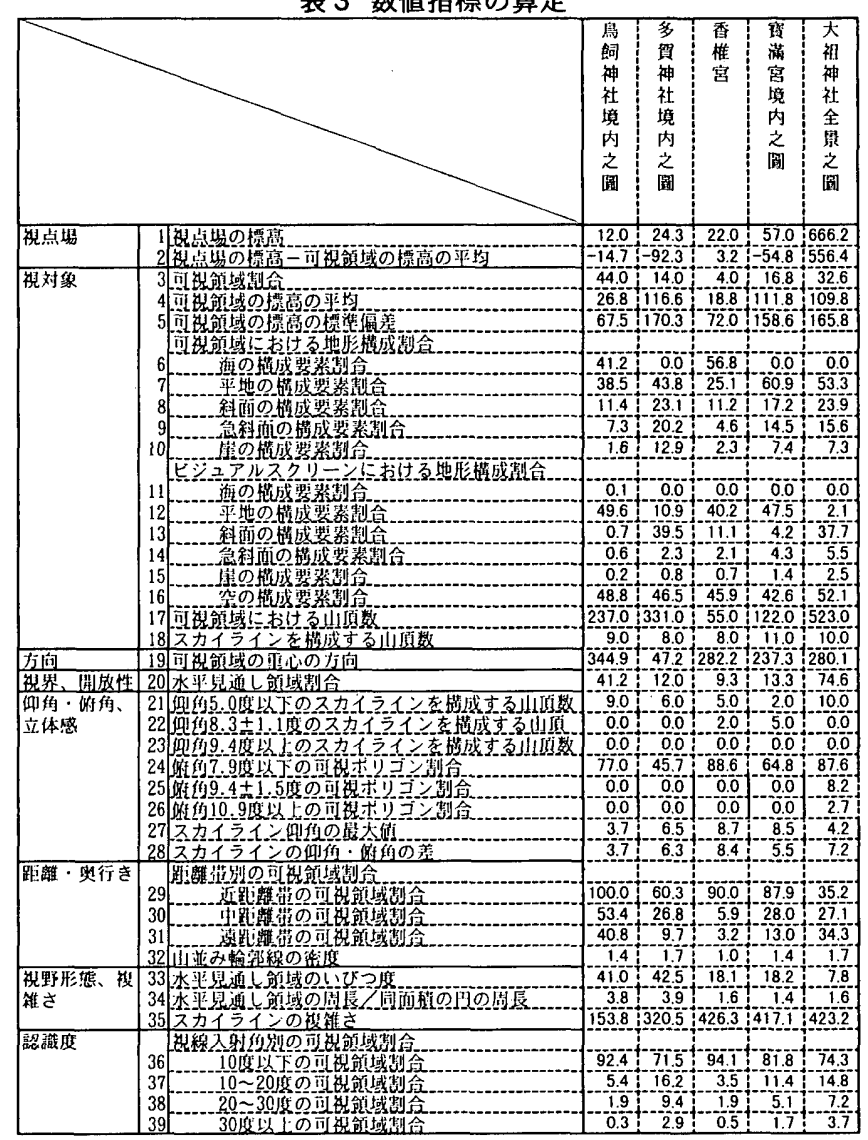

を併用し考察することが最も適切である。

（3）本システムは、実測や地図、写真上では計量困難な景観の 特徵を明瞭かつ簡便に表現できるという利点がある。

（4）数值地図を用いているため、システムの汎用性は高く、日 本の他の地域にも容易に適用できる。また、陸地のみらなず海上 を視点場とした計測も可能である。

（5）本システムで提案した指標と心理評価の関連を明らかにす ることで、良好な景観を有する視点場の探索にも活用できる。

（6）景観の特性を数值として表現できることから、景観整備、 計画における実証的な判断材料として用いることが可能である。

（7）計算半径が $15 \mathrm{~km}$ を超えると、可視・不可視の算定、ビ ジュアルスクリーンの計算に多大な時間が係るため、さらなる改 良を加えたい。

（8）地形は 3 角形ポリゴンによって分割したモデルであるが、 その分割手法は複数ある。将来的には、利用者が、実際の地形状 況と各地形モデルとの誤差を簡便に評価し、地形モデルの分割手 法を自由に選択できるようなシステムに改良したい。

\section{参考論文}

1）樋口忠彦：景観の構造、技報堂、1975

2）上原敬二：日本風景美学、大日本出版、1943

3) 山田学：都市設計におけるグラフィックスディスプレ一の応用、 都市計画別冊、6 号、日本都市計画学会、pp.191 196、1971

4 ）小柳武和：詈観計画のための情報処理技術 一自然地形情報の処 理および透視図の自動作成プログラムー、土木学会第 33 回年次学 術講演会講演概要集IV、pp.143 144、1978.9

5 ) 石田克紀、小柳武和、山形耕一、志摩邦雄：日立市域の精密 D T Mの作成とその応用、第 17 回土木情報システム論文集、pp.41〜48、 1992 
6 ) Burrough,P.A. and De Veer,A.A. : Automated production of landscape maps for physical planning in The Nertherlands., Landsc. Plan, No.11, pp. 205 226, 1984

7 ) 磯田節子、両角光男、位寄和久:ランドマークの可視・不可視領 域に着目した大規模建築物の影響評価モデルの検討、日本建筑学 会計画系論文報告集、No.456、pp.163 169、1994.2

8 ）飯塚英雄 : 市街地から見た山の可視部分の計量化とその分布図の 作成、日本建築学会第 16 回情報システム技術利用シンポジウム、 No.16、pp.439 443、1993.12

9 ）坂井猛、萩島哲、出口敦、鵤心治：メッシュテータによる視点場 探索手法の開発、都市計画論文集、No.30、pp.253〜258、1995

10）有馬隆文、佐藤誠治：「数值地図」を用いた CG による地理的スケ 一ルの都市景観分析、日本建築学会第 17 回情報システム技術利 用シンポジウム、No.17、pp.325〜330、1994.12

11) Yuka Himeno, Seiji Sato, Takafumi Arima, Yuji Kobayashi : Landscape Potential Using Visual Composition of Large Scale Landscape Element, The Proceedings of International Symposium on City Planning 1998, pp.441 448, 1998.10

12）䳋田瑞代、萩島哲、鷠心治、有馬隆文：名所図会に描かれた景観 の地理的構造に関する研究 (その1)、日本建築学会大会学術講演 梗概集（九州）F-1、pp.519〜 520、1998.9

13）有馬隆文、萩島哲、鵳心治、鳪田瑞代 : 名所図会に描かれた景観 の地理的構造に関する研究 (その 2$)$ 、日本建築学会大会学術講演 梗概集 (九州) F-1、pp.521 522、1998.9

\section{蔽注}

注 1 ）標高データを基にして作成した地形のシミュレーションモデル をDTM (Digital Terrain Model) という。またディジタル標高モ テル：DEM（Digital Elevation Model）と呼ばれる場合もある。
注 2 ) 「数值地図」は建設省国土地理院が測量法に基づき刊行するも のであり、「数值地図」にかかる著作権その他の権利は、全て 建設省国土地理院に鯆属される。

注 3 ）国土地理院の 50m 地形メッシュは、緯度、経度を基準として分 割したものであるため、地域によって、メッシュの縦横の大き さは異なる。

注 4 ）人間が把握する視覚的な像を正確に投影できるものは球である。 したがって、円筒状のスクリーンに投影する場合、視点の直下 方向や天頂方向にひずみが生じる。しかし、本研究では水平士 $30^{\circ}$ の䇺囲を計量の対象としており、また、実際に描かれる山 並みのスカイラインは水平 $0 \sim 15^{\circ}$ の箸囲内であるため、スク リーンに投影した像は人間が視覚的に捉える像に非常に近いと 言える。

注 5 ）桷口は「景観の構造（pp.43）」 ${ }^{1)}$ において、立った姿乵、およ び座った姿勢での標準的な視野の方向を基にしてディスプレイ に最適な領域を定義している。

注 6 ) システムは 3 つのブログラムに分かれている。「景観特性計量 プログラム」は、Tcl/Tkを用いて GUI を構筑しており、主要計 算部分を C 言語によって記述している。「3 次元 CG 表示プログ ラム」「ビジュアルスクリーンCG 表示プログラム」は、現在 のところ、GUI を有しないが、将来的には 3 つのプログラムを 統合し GUI を有するアプリケーションソフトウエアにする予定 である。また、本システムに関する情報を http://urban.arch.kyushu-u.ac.jp/ari.lab/dls.htm に公開している。

（1998年11月 5 日原稿受理， 1999年 3 月 26 日採用決定） 